\title{
Article \\ Obtaining Forest Biomass for Energy Purposes as an Enterprise Development Factor in Rural Areas
}

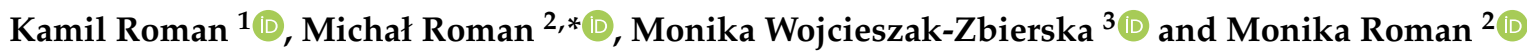 \\ 1 Institute of Wood Sciences and Furniture, Warsaw University of Life Sciences, Nowoursynowska 159, \\ 02-787 Warsaw, Poland; kamil_roman@sggw.edu.pl \\ 2 Institute of Economics and Finance, Warsaw University of Life Sciences, Nowoursynowska 166, \\ 02-787 Warsaw, Poland; monika.wojcieszak@up.poznan.pl \\ 3 Faculty of Economics, Poznań University of Life Sciences, Wojska Polskiego 28, 60-637 Poznań, Poland; \\ monika_roman@sggw.edu.pl \\ * Correspondence: michal_roman@sggw.edu.pl
}

Citation: Roman, K.; Roman, M.; Wojcieszak-Zbierska, M.; Roman, M. Obtaining Forest Biomass for Energy Purposes as an Enterprise Development Factor in Rural Areas. Appl. Sci. 2021, 11, 5753. https:// doi.org/10.3390/app11125753

Academic Editor: Seonghun Kim

Received: 13 May 2021

Accepted: 14 June 2021

Published: 21 June 2021

Publisher's Note: MDPI stays neutral with regard to jurisdictional claims in published maps and institutional affiliations.

Copyright: (c) 2021 by the authors. Licensee MDPI, Basel, Switzerland. This article is an open access article distributed under the terms and conditions of the Creative Commons Attribution (CC BY) license (https:/ / creativecommons.org/licenses/by/ $4.0 /)$.

\begin{abstract}
This article presents how selected factors related to forest biomass affect enterprise development in rural areas. The study used a multivariate analysis of variance (ANOVA), as well as the AHP operational research method. The following factors were selected for analysis: conifer timber harvesting, sales of renewable fuel in the form of briquettes to selected customers, and the number of the given company's regular customers. Their selection was determined by the fact that using plant material for energy purposes has become significantly more popular in recent years. This particularly includes forest biomass, which is increasingly used as an energy commodity in the Polish heating industry. Forest biomass is a biodegradable raw material generated in the form of waste during wood production and processing, as well as during sanitation cutting. The study was conducted using a diagnostic survey method with a survey questionnaire in the first quarter of 2020. It included 614 owners of small and medium-sized enterprises operating in various rural areas across all of Poland's voivodeships. The study was conducted using the CATI method. Analyses defining the dependence of specific factors on the examined parameters and supporting the priority nature of the given actions may show the development of particular pro-ecological actions in a given area. In one case, the critical level of significance determining the assignment of the analyzed factor to a specific homogeneous group was below 0.05 . This means that there was a correlation between the sales of renewable fuel in the form of briquettes to selected customers and the number of enterprises in the voivodeship. Therefore, due to the sales of renewable fuel in the form of briquettes to selected customers, the greatest development prospects for wood industry companies existed in the Małopolskie, Mazowieckie, Śląskie and Wielkopolskie Voivodeships.
\end{abstract}

Keywords: environmental; biomass; briquette; farms; Poland; rural areas

\section{Introduction}

In recent years, there have been many improvements in the heating and power industry thanks to innovative green solutions [1]. This is due to the obligation to adapt the national energy policies to the targets of the European Union (EU). Based on the current legislation, biomass is partially used in heating and power plants. Such actions are directly related to reducing greenhouse gas emissions using "clean development" mechanisms [2]. The idea of limiting adverse environmental impacts was ratified at the United Nations conference in Kyoto, which contributed to the enactment of Directive 2003/87/EC aimed at limiting the exploitation and overuse of fossil fuels.

In the era of a fuel crisis, global sanctions, ever-increasing energy demand, and climate disruption, bioenergy is the most prominent and fastest-growing economic direction [3]. Bioenergy development makes it possible to use renewable raw materials as an alternative fuel, creating local competitiveness and enabling independence from other countries [4]. 
Biomass from biodegradable waste, as well as forestry and agricultural by-products, is a resource featuring a significant energy potential [5]. Most of the research results included in the literature concern the densification of three generally available biomass types, i.e., energy crops, wood industry (sawmill) waste, and small-size raw materials harvested in forests.

Sustainable development efforts resulting from the EU policy have increased interest in the possibilities of using and managing generally available, environmentally friendly waste material from forest areas, both in Poland and the rest of the world [6]. Such material includes natural waste generated on forest land, as well as waste residues from raw material processes conducted by the forestry products industry. The collected forest wastes resulting from logging operations have been referred to as forest biomass [5]. It includes, among others, firewood in the form of chips and smallwood forestry waste such as branches, treetops, poles, bushes, brushwood and snags, as well as wood industry waste (chips, sawdust). An increasing interest in waste materials that have never been commonly used for fuel and energy purposes is also noticeable in forest management. Considering their small size, such materials are typically made and used by local residents or resold for token sums of money [7].

The terminology concerning this resource has not been standardized. The literature defines it as logging residue, post-logging residue, or logging smallwood [8]. Logging residue is the material created while harvesting timber [9]. After harvesting (logging), branches and treetops should be cleaned and gathered in piles in the harvest area or near export roads to prepare the area for reforestation; additionally, they can be shredded and mixed with the soil using specialized machinery [10]. Logging residues are characterized by high bark and needle contents [11].

The literature review indicated that Poland's current forest areas amount to about 9.2 million hectares, which corresponds to about $29.6 \%$ of its total territory. The climatic and habitat conditions are conducive to the development of conifers, which account for $69.6 \%$ of the total forest area [12]. The most common and most frequently harvested tree species in Polish forests is the Scots pine (Pinus silvestris L.), also called the European red pine [13]. The timber industry's potential can be expressed by its production capacity. A total of $31,688,773 \mathrm{~m}^{3}$ of coniferous timber was harvested in Poland in 2019 (Figure 1).

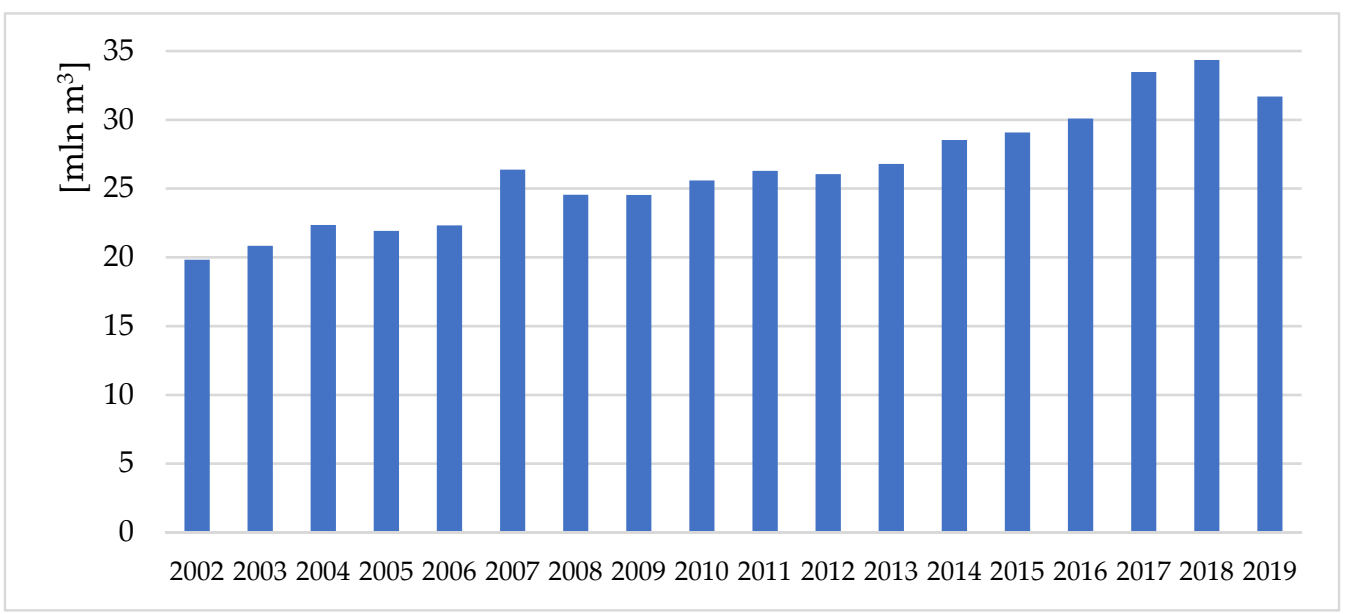

Figure 1. Conifer timber harvesting in Poland in the 2002-2019 period. Source: [14].

Large quantities of waste are generated during the logging process, including logging residues [15]. Logging residues are mainly branches and treetops [16]. The proportion of logging residues varies, although is typically about $15 \%$. Estimates show that about 5.5 million $\mathrm{m}^{3}$ of logging residues are generated in the process of felling 31.5 million $\mathrm{m}^{3}$ of coniferous timber [17]. The wood material is processed by turning it into chips using a chipper [18]. Table 1 shows the percentage share of individual wood parts in the total mass of a pine tree, as described in the literature. 
Table 1. The percentage share of individual wood parts in the total mass of a pine tree.

\begin{tabular}{|c|c|c|}
\hline Item & Properties & Reference \\
\hline \multirow{5}{*}{1} & - longitudinal thickness: $64 \%$ & \multirow{5}{*}{ [19] } \\
\hline & - stacked thickness: $8 \%$ & \\
\hline & - general limb: $5 \%$ & \\
\hline & - brushwood: $7 \%$ & \\
\hline & - roots: $16 \%$ & \\
\hline \multirow{5}{*}{2} & - wood arrows: $61 \%$ & \multirow{5}{*}[20]{} \\
\hline & - bark arrows: $8 \%$ & \\
\hline & - branches: $12 \%$ & \\
\hline & - needles: 3\% & \\
\hline & - snag: $16 \%$ & \\
\hline \multirow{3}{*}{3} & - treetops, branches, needles: $20 \%$ & \multirow{3}{*}{ [20] } \\
\hline & - branches thinner than $40 \mathrm{~mm}$ and needles: $15 \%$ & \\
\hline & - branches thicker than $40 \mathrm{~mm}: 5 \%$ * & \\
\hline \multirow{3}{*}{4} & - trunk $69 \%$ & \multirow{3}{*}{ [21] } \\
\hline & - treetop, branches $16 \%$ & \\
\hline & - stump, roots $15 \%$ & \\
\hline
\end{tabular}

${ }^{*}$ Refers to biomass that is the aboveground portion of the harvested wood. Source: [19-21].

The percentage share of individual wood parts in the total pine tree mass indicates the volume of forest biomass created when harvesting the timber. The estimated amount of logging residues indicates that the methods of managing them should be discussed. Although logging residues can be left in the harvesting area to act as a fertilizer, using them as solid fuel makes it possible to create an additional renewable energy source [22]. Forest residues are also a by-product and represent fully renewable resource, as a potential source of fuel. Their usage is ecologically justified, because during direct combustion, they can reduce the air pollution. This has huge importance in installations using fossil fuels, because according to the forecast, some coal sources in Poland may be exhausted in the near future [22].

Theoretically, fossil fuel can be replaced by forest residues, although their energy content will not correspond to the energy value of coal. In Poland, about 38 million $\mathrm{m}^{3}$ of wood (thick wood) are harvested. Based on the literature values [8], it can be concluded that roughage constitutes about $72 \%$ of the total harvested wood. The remaining $15 \%$ is roots and stumps, while $13 \%$ is small-sized wood, including forest residues. The estimated potential of small-sized wood mass is about 4.9 million $\mathrm{m}^{3}$. Assuming that the energy value of forest residues in the natural state is about $12 \mathrm{MJ} \cdot \mathrm{kg}^{-1}$ and the density of pine is $550 \mathrm{~kg} \cdot \mathrm{m}^{-3}, 32,340 \mathrm{TJ}$ of pure energy can be obtained from the forest residues.

Taking action aimed at managing forest residues is justified by the insufficient data on the possibilities of their use, and as such, analyzing this issue will make it possible to gather more information.

\section{Literature Review}

Rural development is the subject of much research in various scientific disciplines due to its multifaceted and multidimensional nature [23-39].

One of the reasons for it is the opportunities offered by rural areas due to the presence of natural resources [40]. The importance of agriculture is yet another vital aspect of rural research, because agriculture goes beyond the economic dimension and also involves social and environmental aspects, with its characteristics and transformation directions also affecting the scope of implementing sustainable rural development concepts [41-46]. 
Apart from providing quality food, the goals of sustainable agriculture include preserving agricultural resources, protecting biodiversity, ensuring the economic viability of agriculture and the local communities, maintaining rural cultural values, as well as contributing to the overall sustainable development. Forestry has similar goals [47].

The published research results show that the importance of using forest products and their intermediates for the given community depends on many factors, including economic, institutional and demographic aspects, as well as forest resource structures [48,49]. Their importance is increasingly often recognized, but it has not been fully examined.

The company environment is strictly dependent on two-stage cooperation. In the first environment (micro-environment), for example, we have to deal with the different types of companies and businesses. In second environment (macro-environment), the country's economy must be considered, i.e., the economically autonomous region. The environment of the production system affects the functioning of the system, just as the production system affects the nature of this environment. The two-stage company environment is presented in Figure 2.

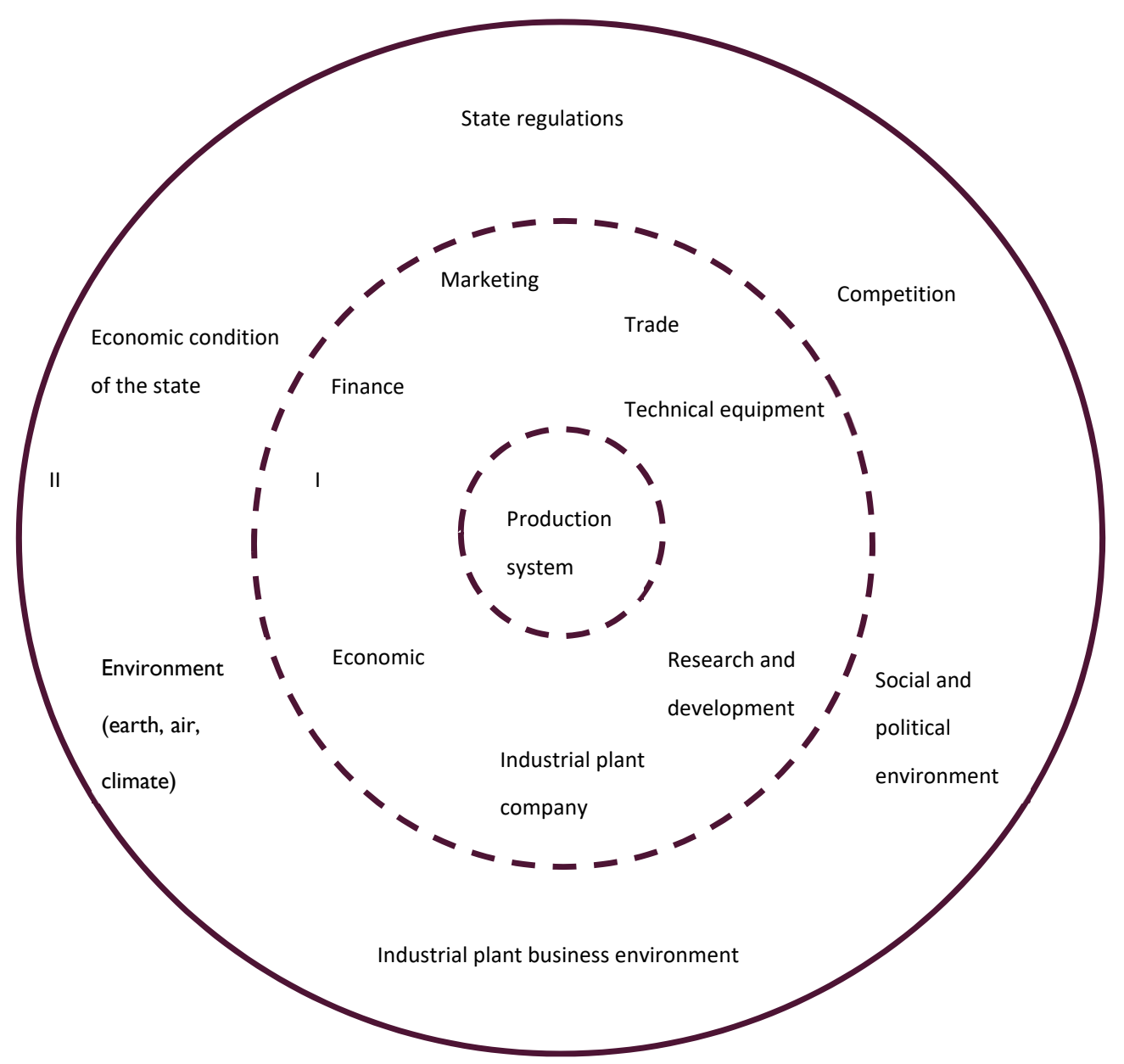

Figure 2. The two-stage company environment.

In the first-degree environment, we can list various factors influencing the organization of the system. These factors are formed naturally, enabling the functioning of the company environment along with the processes taking place in it. Factors can be divided into soft factors that interfere with the substantive features of the enterprise (such as knowledge or information), and hard factors, such as material, raw material, or finished product. An example of soft factors could be executive and management staff employed, where the knowledge of CEOs or decision-makers managing the company plays a fundamental role. Conducted research and development projects or grants are equally important, because 
thanks to them the company has a chance to implement new products, and therefore to penetrate new market areas. Possession of technologies for storage, information processing, and data transmission, especially in terms of logistics during production processes, it is undoubtedly an important aspect of a properly functioning system in every enterprise. Among the soft factors, economic and accounting services stand out as a supporting process that maintains the proper flow of capital in the enterprise.

The use of forest biomass for energy purposes should be based on sustainable forest management. Sustainable forest management can be based on the use of forest biomass for energy purposes [50]. Moreover, it is vital to take care of environmental resources and minimize production risks at the same time. Therefore, showing the impact of selected factors on the possibility of managing forest biomass and utilizing it for energy purposes may be an interesting issue.

Today, global civilization development is causing a high and steadily growing demand for energy. At the same time, the rising awareness of the need to care for the environment and prevent climate change means that developing renewable energy sources and increasing the share of renewable energy are among the key strategic activities aimed at ensuring energy security in European Union countries, including Poland [51]. This is a difficult task for Poland because the Polish energy sector is primarily focused on using hard coal and lignite, with renewable energy being treated merely as an alternative to fossil fuels. As indicated in the literature [52], wood is a natural and ecological resource and remains so at each stage of its production process-from harvesting to processing to creating end products to its decommissioning-and it is also one of the oldest energy commodities. This duality, which is characteristic of woody biomass, defines the areas of its possible application. As indicated by [53-55], this raises a dilemma related to the rationality of using wood for alternative purposes, i.e., deciding whether it should be used as a production material or for energy purposes.

The substitution of competitive non-environmentally friendly materials by wood in structures also contributes to the direction of climate change mitigation. Energy production is the last option among the utilization applications of forest biomass (through a biorefinery approach). Nevertheless, significant amounts of residues can still become the feedstock of biofuel production.

This is mainly due to the efforts to prevent adverse climate change, as well as the goal of increasing energy security and diversifying the energy sources available in the international arena. The current EU energy policy and Member State national strategies establish more and more legislative frameworks and commence actions to accelerate the renewable energy source development process to find alternatives to conventional sources, including increasing the use of woody biomass as an energy commodity [56]. In Poland, plant materials for energy purposes have gained popularity in recent years, particularly forest biomass, which is being used as an energy commodity in the Polish heating industry more and more often (Figure 3).

Due to their significant fuelwood capacity, forest areas require supervision to regulate forest resources and ensure a steady supply of renewable energy resources. As an institutionalized form, the market of woody biomass for energy purposes is relatively new, and its emergence is a consequence of the need to replace traditional fossil fuels with renewable energy sources. In economic terms, it refers to all relationships between the participants of woody biomass buying and selling transactions. The wood, energy and agricultural markets are all directly related to the market of woody biomass for energy purposes, while also conditioning its operation at the same time. In turn, the market's supply side includes all suppliers of biomass that can be processed to obtain energy, whereas the demand is driven by energy generators interested in purchasing such biomass, i.e., households and commercial, industrial, and municipal energy providers. The intermediaries in the sale and purchase transactions are also part of the market of woody biomass for energy purposes. 


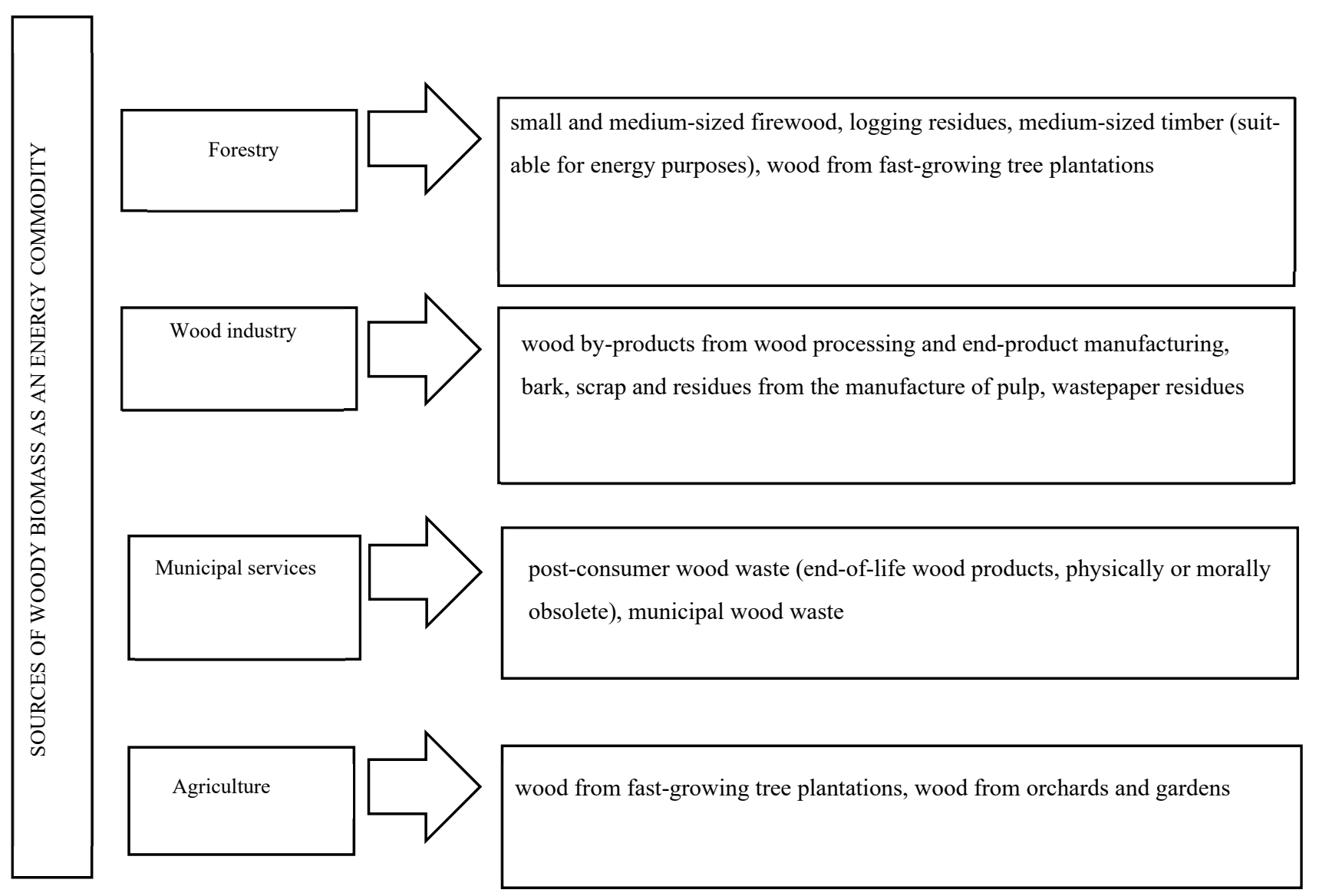

Figure 3. Forest biomass sources. Source: [57].

Woody biomass is an important renewable energy commodity obtained by natural processes. Energy from other renewable sources is also increasingly often used in Poland, e.g., solar radiation, wind power, geothermal, aerothermal and hydrothermal energy, non-woody biomass, etc., based on the location, terrain and climatic conditions. Woody biomass is classified as solid biomass, and along with biogas and bioliquids, belongs to the general category of biomass. Generating energy using biomass is deemed to be low capital-intensive and is considered the fastest way for Poland to meet its international commitments for the production of heat and electricity using renewable sources. Biomass production is essentially spontaneous and occurs through the reaction of solar radiation and photosynthesis, resulting in $470 \mathrm{~kJ}$ of chemical energy being accumulated in carbohydrates synthesized from one mole of $\mathrm{CO}_{2}$ [57]. The advantage of wood as an energy commodity lies in its specific technical and functional properties; therefore, tree biomass is predominant among energy commodities classified as solid biomass. Firstly, this is due to its relatively high calorific value and low emissions (generating the same amount of $\mathrm{CO}_{2}$ in the combustion process as that which was absorbed during vegetation). Secondly, it is thanks to its relatively low content of non-flammable minerals and trace content of sulfur compounds, as well as the high melting point of the ash produced by combustion. As stated before, the very nature of wood results in woody biomass for energy purposes being obtained primarily from the forestry and wood sectors (including the timber industry and its auxiliaries, the pulp and paper industry and the furniture industry). Agriculture is yet another source of such biomass. The literature $[51,58,59]$ indicates that woody biomass of various types, i.e., roundwood, wood by-products (forestry and wood processing waste), as well as post-consumer wood waste, may be used as an energy commodity. It may vary in form and size. Firstly, it can be in unprocessed (e.g., rolls, billets, edgings), shredded (e.g., chips, sawdust, bark), processed (logs) or compacted (pellets, briquettes) forms. However, it must be pointed out that woody biomass for energy purposes may significantly 
differ in regard to its density, moisture content, calorific value, chemical composition and impurity content (mineral, chemical, etc.), depending on its form, type, degree of processing and place of generation, even though the chemical composition of woody biomass does not present high variations.

The energy conversion process requires biomass of stable quality, both in terms of physical (moisture content) and chemical properties (volatile ingredients, calorific value), as well as of adequate fineness and homogeneity, and without impurities [57]. The process can take the form of direct combustion, co-combustion with coal, or thermal disposal combined with pyrolysis and gasification, focused on either heat or heat and power production [56,57].

During the production processes, along with the flow of the processed element, there are continuous changes aimed at using the available input resources, and then processing them into factors supplying subsequent processes or finished products. Repetitive production activities create the concept of a production system with the possibility of interfering with some of its stages [60]. This system is understood as a set of interrelated elements that interact with each other, and this interaction usually takes the form of a feedback. The production system itself is a deliberately designed and organized energy and information system, exploited to produce specific goods (products or services) in order to satisfy the various needs of consumers. According to the literature, the production system consists of five basic elements [61]:

- Input vector $X$, which includes all factors of production;

- Output vector $Y$, which includes products, services, and various types of harmful waste;

- Input vector through processes into the output vector, called the production process;

- System management process;

- Material, energetic and informational interfaces between the above-mentioned components of the production system.

Generally speaking, a production system is a system of constituent elements and relationships between them, and relationships of the transformation of input factors to exit factors of the system. The ordered form of the system relates to a set of activities (operations, activities) aimed at producing specific products, as a result of which the recipient (potential user) receives products (product or service). Among the listed elements, some processing or production subsystems, as well as the production process management subsystem can be distinguished [62]. The elements of the system, in which we can specify the input vector $\mathrm{X}$, the output vector $\mathrm{Y}$, the processing processes taking place between them, as well as the material, energy and information interfaces taking place in the process, are collectively called the processing or production subsystem. The system elements responsible for the system management process and information feedback are referred to as the management subsystem [63].

The operation of the production system is strictly dependent on the two-stage system environment. In the first environment (micro-environment), for example, we have to deal with the different types of companies and businesses. In the second environment (macro-environment), we take into account the country's economy, i.e., the economically autonomous region. The environment of the production system affects the functioning of the system, just as the production system affects the nature of this environment.

Woody biomass is the most widely used energy commodity among the commercially available types of plant biomass [64]. This is because it has the greatest technical potential of all renewable energy sources. The development of the market of woody biomass for energy purposes may affect regional development, because it enables the efficient use of existing local resources (land, forest areas, human resources) [65]. The development of renewable energy sources, including woody biomass for energy purposes, is conditioned by legal and economic aspects and requires active support through legal and financial instruments to make renewable technologies competitive in the energy markets [66].

As previously indicated, developing alternative energy sources to fossil fuels is a necessity, and the production and use of renewable energy -including woody biomass-is 
becoming a sustainable development determinant, not only in environmental but also in social and economic dimensions [67].

In Poland, wood by-products have been used as an energy commodity for many years; however, they are mainly used in the wood sector and to some extent in households, small municipal boiler plants and public utility institutions (e.g., schools, hospitals, residential facilities, etc.). Recent years have shown that along with the increasing role of renewable energy sources in the energy industry, wood by-products have become an important energy commodity in the energy sector. It should be emphasized that despite the significance of wood by-products in economic practice, until recently there was a major information gap regarding their supply and usage for energy purposes, as is the case with other woody biomass energy commodities [64].

\section{Research Objectives and Methodology}

This article presents how selected factors related to forest biomass affect enterprise development in rural areas. The study used a multivariate analysis of variance (ANOVA), as well as the AHP operational research method. The result of the ANOVA was confirmed using Duncan's post hoc test to assign the results to a specific homogeneous group. The following factors were selected for the analysis: conifer timber harvesting, sales of renewable fuel in the form of briquettes to selected customers, and the number of the given company's regular customers. The factors selected belong to both the closer and wider environment. Factor selection was determined by the fact that plant materials used for energy purposes have become widely known in recent years. This particularly includes forest biomass, which is increasingly often used as an energy commodity in the Polish heating industry. The study was conducted using a diagnostic survey method with a survey questionnaire in the first quarter of 2020. The research was conducted using the CATI (computer-assisted telephone interviewing) method and included 614 owners of small and medium-sized enterprises (SMEs) operating in rural areas across all of Poland's voivodeships, which accounted for $2 \%$ of the total number of enterprises in the category analysis. The enterprises for the study were selected in a purposive manner.

Using shredded logging residues fits into the concept of entrepreneurship [68] because it can prove to be a venture with high economic potential [69]. Implementing the concept of utilizing shredded logging residues requires analysis, which in the case of this article was conducted using the methods available. Table 2 summarizes the data used in the analysis, broken down by the province of Poland. The data describe factors that can affect business growth.

\subsection{Using ANOVA to Measure the Selected Factors}

A multivariate analysis of variance (ANOVA) was used to develop the results. This method explains the probability with which the extracted factors can cause differences between the observed group means. The analysis of variance technique was created in the 1920 s by Ronald Fisher. The method makes it possible to determine how selected factors $(\tau, \varphi)$ affect the output parameter $f$ and the mutual relationships between the parameters analyzed, assuming that the remaining factors are constant, i.e., all else held constant, which is shown in Equation (1).

$$
\omega=f(\tau, \varphi)
$$

The value $\alpha$, which indicates the level of significance, was considered during the analysis to express the probability of error when selecting the confidence coefficient [70]. The assignment of a factor to a particular homogeneous group is determined by the critical significance level. The test probability value $\alpha$ was taken to be 0.05 , representing the difference between unity and the confidence coefficient $F$ with a value of 0.95 , i.e., $F=1-\alpha$. The "nature of the problem" and the accuracy of the distribution of averages affected the results of the analysis as well [71]. Determining the resulting between-group error involved 
calculating the ratio of the sum of the between-group squares to the number of degrees of freedom [72]. The between-group error can be determined using Equations (2)-(4).

$$
\begin{gathered}
S S_{T}=\sum_{i=1}^{a} m_{i}\left(\bar{y}_{(i)}-\bar{y}_{(\ldots)}\right)^{2} \\
d f_{T}=a-1 \\
M S_{T}=\frac{S S_{T}}{d f_{T}}
\end{gathered}
$$

where:

$m_{\mathrm{i}}$-The number of units in each group;

$a$-The number of groups compared in the analysis of variance, the number of levels of the factor;

$\bar{y}_{(\ldots)}$-The overall mean, for all observations;

$\bar{y}_{(i)}$-The mean average for a given level of the factor, for the study group;

$S S_{T}$-The sum of squares between the subjects and between the groups;

$d f_{T}$-Degrees of freedom between the subjects and between the groups;

$M S_{T}$-Between-group variance.

Using a multi-class analysis of variance made it possible to examine the impact of factor effect combinations on the population. Equation (5) shows the theoretical model of the analysis.

$$
X i j k=x s r+a i+b j+c k+(a b) i j+(a c) i k+(b c) j k+(a b c) i j k+e i j k l
$$

where:

Xsr-Overall mean, for the entire population;

$a i-$ The effect of factor A at level $i(i=1,2, \ldots, n)$;

$b i-$ The effect of factor B at level $i(i=1,2, \ldots, k)$;

$c k$-The effect of factor $C$ at level $i(i=1,2, \ldots, m)$;

(ab)ij-Interaction effect of factors $\mathrm{A}$ and $\mathrm{B}$ at levels $i$ and $j$, respectively;

(ac) $i k$-Interaction effect of factors $\mathrm{A}$ and $\mathrm{C}$ at levels $i$ and $k$, respectively;

$(b c) j k$-Interaction effect of factors $\mathrm{B}$ and $\mathrm{C}$ at levels $j$ and $k$, respectively;

(abc)ijk-Interaction effect of factors A, B and C at levels $i, j$ and $k$, respectively;

$e i j k l-$ Random error with normal distribution, mean equal to zero and constant variance.

In the case studied, the ANOVA method makes it possible to determine how the individual factors affect the output parameter, as well as to determine the mutual relationships between the parameters analyzed. The numerical interval, estimated with an assumed probability as a confidence interval, contained the true, unknown value of the parameter belonging to the general population, which was characterized by vertical bars with a value range of 0.95 . Confidence intervals can be determined for the arithmetic mean. The probability of determining the actual location of the specific parameters was defined by a confidence coefficient $(1-\alpha)$ (percentage confidence interval $100(1-\alpha)$ ). The critical significance level, based on which a factor is assigned to a particular homogeneous group, should be less than $5 \%$. 
Table 2. Summary of data on selected factors by the province of Poland.

\begin{tabular}{|c|c|c|c|c|c|}
\hline Voivodeship & $\begin{array}{l}\text { Number of All } \\
\text { Enterprises in the } \\
\text { Voivodeships }\end{array}$ & $\begin{array}{c}\text { Number of } \\
\text { Enterprises } \\
\text { Surveyed }\end{array}$ & $\begin{array}{l}\text { Coniferous Timber } \\
\text { Acquisition, } \mathrm{m}^{3}\end{array}$ & $\begin{array}{l}\text { Sales of Renewable } \\
\text { Fuel Briquettes to } \\
\text { Selected Customers } \\
\text { (SME) (PLN) }\end{array}$ & $\begin{array}{l}\text { Number of Regular } \\
\text { Customers in the } \\
\text { Enterprises } \\
\text { Surveyed }\end{array}$ \\
\hline Dolnośląskie & 2541 & 40 & $2,760,541$ & $24,333.4$ & 22 \\
\hline Kujawsko-pomorskie & 1628 & 26 & $2,428,896$ & $27,516.5$ & 59 \\
\hline Lubelskie & 1521 & 24 & $1,332,704$ & $38,115.4$ & 37 \\
\hline Lubuskie & 1005 & 16 & $3,050,218$ & $15,579.6$ & 28 \\
\hline Łódzkie & 2078 & 33 & $1,170,489$ & $26,045.8$ & 72 \\
\hline Małopolskie & 5943 & 93 & 864,462 & $31,444.0$ & 24 \\
\hline Mazowieckie & 5095 & 80 & $1,865,031$ & $55,008.5$ & 49 \\
\hline Opolskie & 1007 & 15 & $1,054,616$ & $10,504.8$ & 13 \\
\hline Podkarpackie & 2285 & 36 & $1,583,928$ & $21,122.9$ & 30 \\
\hline Podlaskie & 1008 & 16 & $1,626,952$ & $26,673.5$ & 63 \\
\hline Pomorskie & 2154 & 34 & $4,801,999$ & $22,720.0$ & 30 \\
\hline Śląskie & 4552 & 71 & $1,308,918$ & $24,756.4$ & 36 \\
\hline Świętokrzyskie & 1059 & 16 & $1,108,281$ & $17,491.7$ & 20 \\
\hline Warmińsko-Mazurskie & 1105 & 17 & $2,669,944$ & $22,360.0$ & 46 \\
\hline Wielkopolskie & 4661 & 73 & $3,336,411$ & $41,042.1$ & 69 \\
\hline Zachodniopomorskie & 1533 & 24 & $3,388,714$ & $19,849.3$ & 16 \\
\hline
\end{tabular}

Source: [14].

\subsection{Using the AHP Method for Factor Analysis}

Determining the final results requires the construction of an appropriate structure of the example to be solved, as well as modelling the correct problem hierarchy scheme. The AHP method by Thomas Saaty was used to develop a selection alternative from among the alternatives analyzed. This method requires the construction of an appropriate structure of the example to be solved, as well as modelling the correct problem hierarchy scheme. During the analysis, all elements are compared, forming a variable criteria matrix. Decision suggestions are defined by features located at the successive levels of the problem structure. The accuracy of the alternative solutions increases proportionally to the degree of advancement of the scheme adopted [73,74].

The AHP method can be used in many areas, such as management, political science, sociology, manufacturing and transport. The method belongs to the American school of multi-criteria decision making (MCDM) [74].

The AHP method compares all elements to form a matrix of variable criteria, which expresses the value of specific features. The assigned element values will be written out and compared using the square matrix. The specific features correspond to numerical values, assigned according to priority discretion. Intermediate and even inverse values and are also allowed during the analysis. Inversion occurs when the second element is more important than the first. A specially prepared nine-point rating scale, corresponding to the equivalent factor rank, facilitates assigning the proper numerical values [74]. Table 3 shows the standardized 9-point rating scale.

Table 3. Feature values of the objects analyzed.

\begin{tabular}{cc}
\hline Importance Degree & Explanation \\
\hline 1 & Both elements have the same weight \\
3 & The first element is slightly more important than the second \\
7 & The first element is much larger than the second \\
9 & The first element is much more important than the second \\
Source: [75]. & The first element is decisively more important than the second \\
\hline
\end{tabular}

The "AHP method" calculation software module was used to process the results. The program was developed in the Delhi environment. It features a calculation module in the form of a matrix algorithm that conducts a diagnostic and comparative evaluation of the 
criteria analyzed. The analysis using the AHP method was performed based on selected factors affecting logging residue management in Poland.

\section{Results}

For the ANOVA method, three main output factors and parameters obtained via the surveys were selected. Input parameters (factors) that were selected in the further part of the study were analyzed. The basis for the division of the grouping factor in Table 4 results from the specificity of the ANOVA method, because three basic input parameters and input factors obtained during the survey were selected. The basis for the division of the grouping factor into low, medium and high is an arithmetic division into three sets, with the division consisting of distinguishing three sets whose values were between the minimum and maximum value. The creation of three collections was the assumption in the methodology from the very beginning. Extracting a larger number of sets allows for a more accurate measurement of the analyzed parameters. In the analyzed case, the identification of three sets (low, medium and high) resulted from the value between the maximum and minimum value. The analyzed output factors and parameters are presented in Table 4.

Table 4. Analyzed output factors and parameters.

\begin{tabular}{|c|c|}
\hline Output Parameter & Factors \\
\hline \multirow{3}{*}{$\begin{array}{l}\text { Number of enterprises-subclass } 16.29 . Z \text {, Manufacture of other } \\
\text { wood products } \\
\text { Grouping factor: } \\
\text { - Low, }<20 \text { enterprises in the voivodeship; } \\
\text { - Average, } 20-40 \text { enterprises in the voivodeship; } \\
\text { - High, }>40 \text { enterprises in the voivodeship. }\end{array}$} & Coniferous timber acquisition, (in $\mathrm{m}^{3}$ ) \\
\hline & $\begin{array}{l}\text { Sales of renewable fuel briquettes to selected customers (small } \\
\text { and medium companies-SME) (in PLN) }\end{array}$ \\
\hline & $\begin{array}{l}\text { Number of regular customers in the enterprises } \\
\text { surveyed-Average number of customers (pieces) }\end{array}$ \\
\hline
\end{tabular}

Source: Own study.

The factors presented in Table 4 are the number of enterprises-production of other wood products, acquisition of coniferous wood $\left[\mathrm{in}^{3}\right]$, sale of briquettes from renewable fuels to selected recipients, small and medium-sized companies [in PLN] — and the number of regular customers in the surveyed enterprises-average. The number of customers [in items] has a significant impact on the development of forest biomass production. These are economic factors that show the essence of the functioning of the forest biomass market.

The article presents a model approach with the selected statistical tools usage (AHP and ANOVA). The analysis was carried out in a basic form, which means that the selected factors presented only some of the parameters that can be analyzed in the two-stage company environment. The method can be further developed based on other factors.

The results of the analysis (using the ANOVA method) made it possible to determine how coniferous timber harvesting, sales of renewable fuel in the form of briquettes to selected customers, and the number of regular enterprise customers affect the number of wood processing enterprises. The analysis showed no impact of coniferous timber harvesting on the number of enterprises. The significance level was greater than 0.05 , with $p=0.659$. The empirical value of the statistic was $F(2,13)=0.43139$. Figure 4 shows the relationship between the number of enterprises and conifer timber harvesting.

This was different in the case sales of renewable fuel briquettes to selected customers affecting the number of enterprises. Level of significance: $p=0.034$, where the empirical value of the $F(2,13)$ statistic was 4.4565 . Based on the significance level, the analysis showed a partial effect (medium and high) of renewable fuel briquette sales to selected customers on the number of enterprises. The characteristics of the relationship between the number of enterprises and renewable fuel briquettes sales to selected customers are presented in Figure 5. 


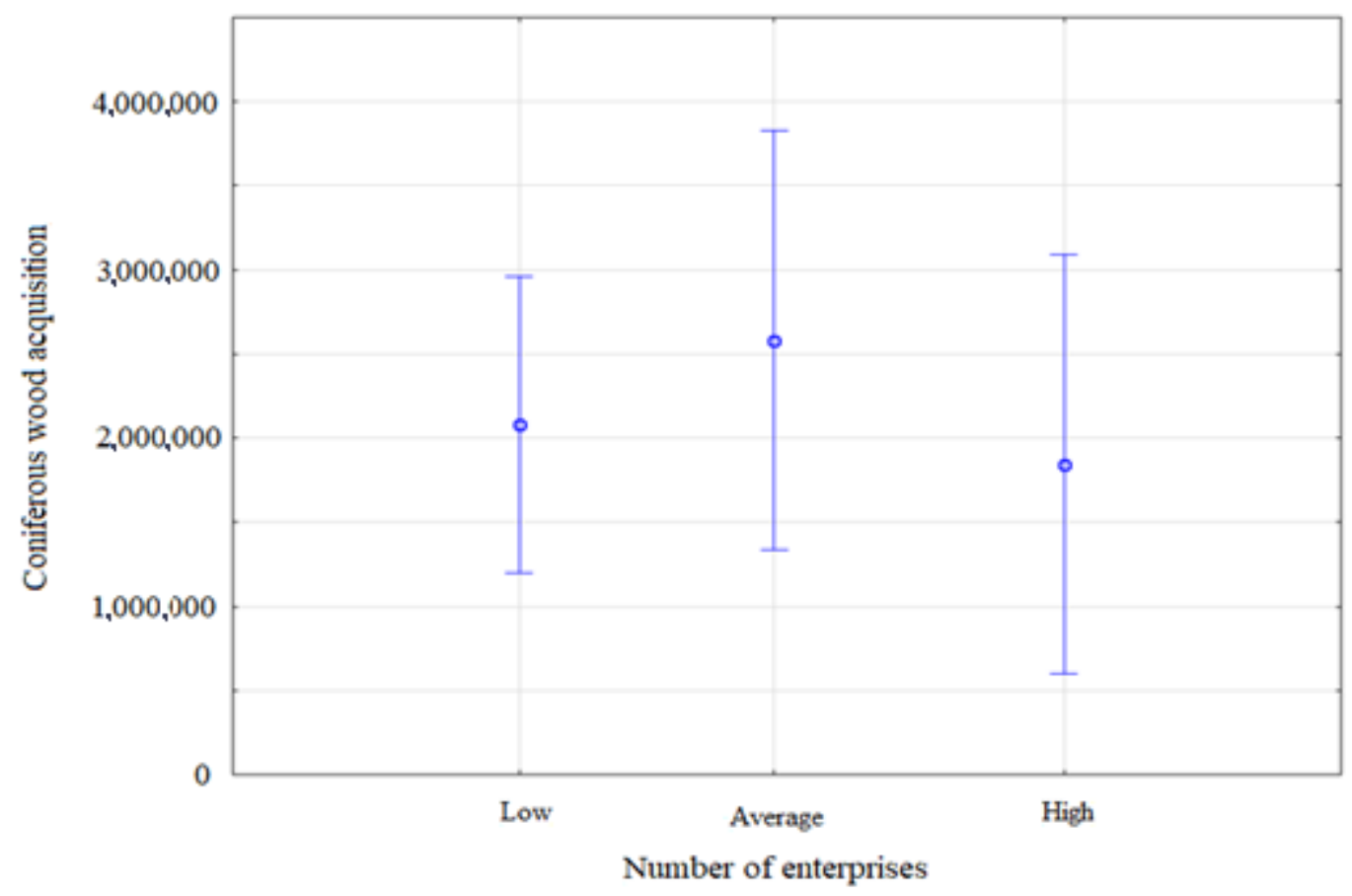

Figure 4. The relationship between the number of enterprises and conifer timber harvesting.

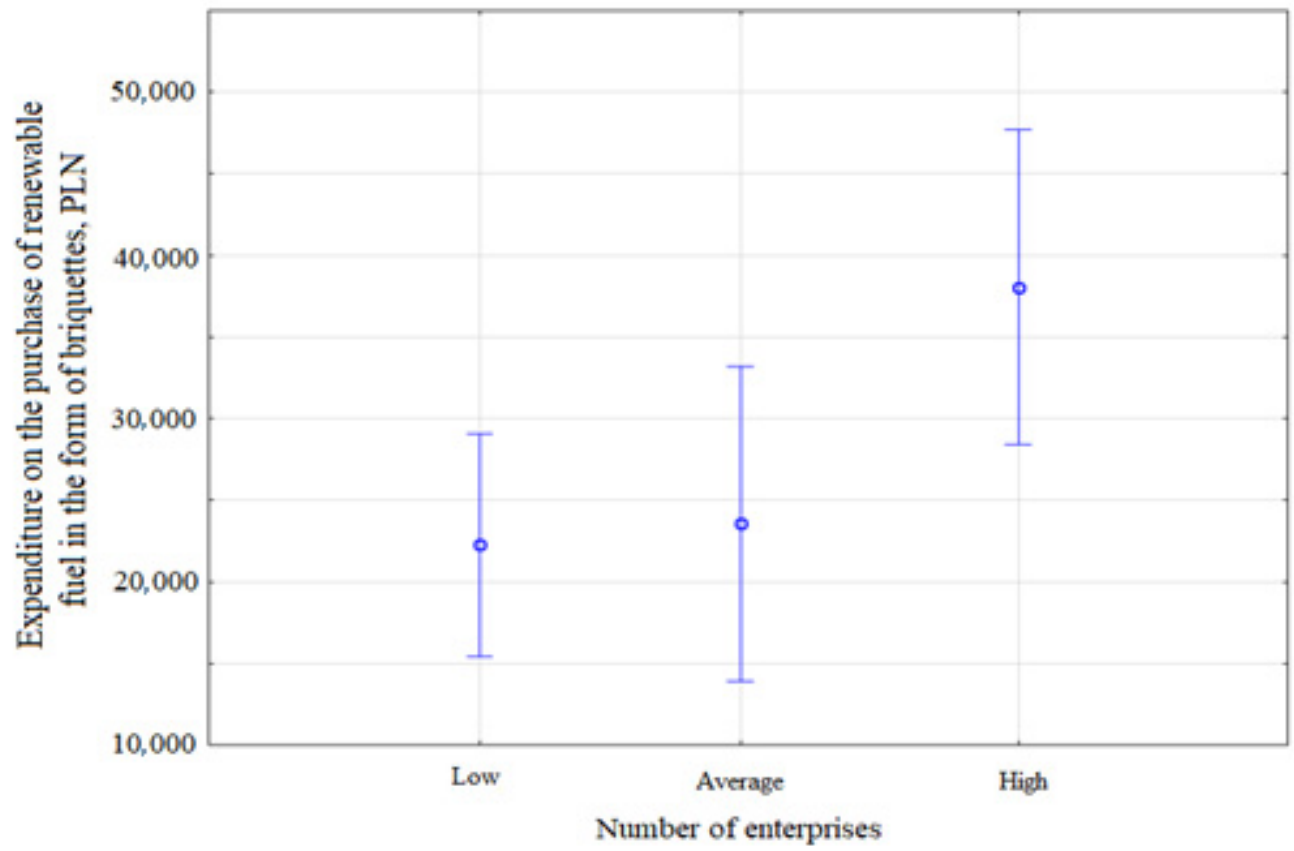

Figure 5. The characteristics of the relationship between the number of enterprises and renewable fuel briquette sales to selected customers.

In the latter case, the results of Duncan's analysis indicated a significant effect on the number of enterprises. There was an increase in business interest in the processing of wood material among enterprises. Table 5 shows the identified homogeneous group relationships between the number of enterprises and sales of renewable fuel briquettes to selected customers. 
Table 5. The relationship between the number of enterprises and renewable fuel briquettes sales to selected customers.

\begin{tabular}{ccc}
\hline \multirow{2}{*}{ Number of Enterprises } & \multicolumn{2}{c}{ Homogeneous Group Based on Duncan's Analysis } \\
\cline { 2 - 3 } & $\mathbf{1}$ & $\mathbf{2}$ \\
\hline Low & $\mathrm{X}$ & \\
Average & $\mathrm{X}$ & $\mathrm{X}$ \\
High & & \\
\hline
\end{tabular}

Analysis of the sales of renewable fuel briquettes to selected customers did not show a significant effect of the studied factor on the number of enterprises established. The analysis showed a significance level of $p=0.759$, for an $F(2,13)$ empirical statistic value of 0.28230 . The analysis conducted (using ANOVA) showed that the number of regular customers had no effect on the number of enterprises. Figure 6 shows the characteristics of the relationship between the number of enterprises and the number of regular customers of an enterprise.

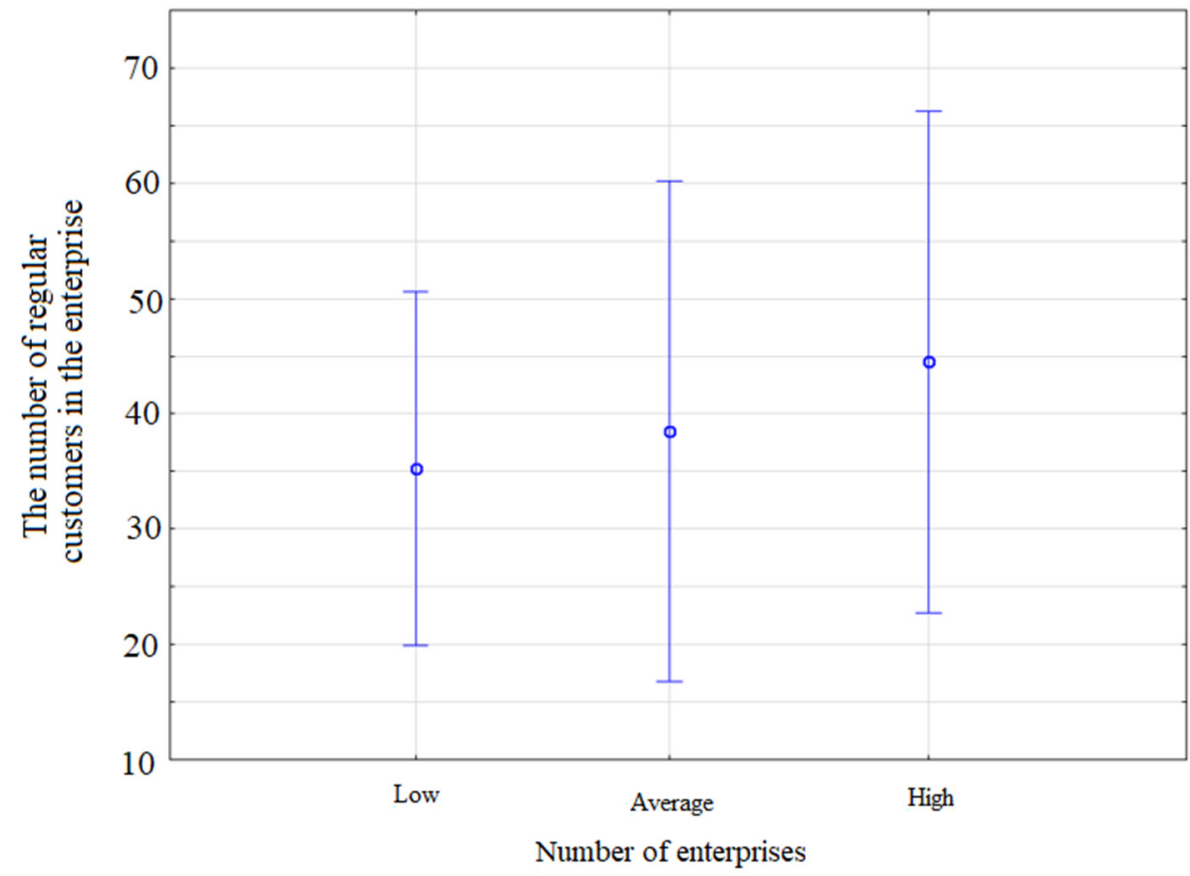

Figure 6. Characteristics of the relationship between the number of enterprises and the number of regular customers of an enterprise.

Applying the analytic hierarchy process (AHP) according to the methodology requires constructing a square matrix along with the assigned factor characteristics. The upper-right corner of the matrix contains the values of the features analyzed. The analysis shows that the highest weight affecting business development among the factors analyzed is the sales of renewable fuel briquettes to selected customers. Table 6 shows the pairwise comparison matrix. 
Table 6. Pairwise comparison matrix.

\begin{tabular}{cccc}
\hline Criteria Preferences & $\begin{array}{c}\text { Sales of Renewable Fuel } \\
\text { Briquettes to Selected } \\
\text { Customers (PLN) }\end{array}$ & $\begin{array}{c}\text { Coniferous Timber } \\
\text { Acquisition }\end{array}$ & $\begin{array}{c}\text { Number of Regular } \\
\text { Customers in the Enterprises } \\
\text { Surveyed }\end{array}$ \\
\hline $\begin{array}{c}\text { Sales of renewable fuel } \\
\text { briquettes to selected } \\
\text { customers (PLN) }\end{array}$ & 1 & 7 & 3 \\
$\begin{array}{c}\text { Coniferous timber acquisition } \\
\text { Number of regular customers } \\
\text { in the enterprises surveyed }\end{array}$ & $1 / 7$ & 1 & 1 \\
\hline
\end{tabular}

Source: Own study.

It must be noted that the selected example is merely a model, because potential enterprise development is affected by a much larger number of factors (both in the closer and wider environment) than just the variables selected for the example. Other factors may also affect the development of the enterprise. For example, this could be competitors, suppliers, customers, producers of substitutes, political and legal factors, technological factors, or knowledge of the market by the enterprise owner. The analysis determined that the maximum eigenvalue of the matrix was 3.0803. The consistency index (C.I.) was 0.0401499 , meaning that it satisfied the consistency condition $\left(\lambda_{\max }-n\right) /(n-1) \leq 0.1$. Figure 6 shows the weight values.

Using the AHP method makes it possible to characterize the case study objectives adopted. Sales of renewable fuel briquettes to selected customers had the highest value, which means that this factor is of the highest importance. Other factors, such as coniferous timber acquisition and the number of regular customers, were at a similar level. The weight values of the AHP method are presented in Figure 7. Weight values can provide the basis for investment activities in this type of enterprises, which entail specific outlays. The development implementation strategy is the result of enterprise investing activity. Mostly, it is a condition for responding to customer expectations, reacting to the actions of the competition, but also increasing the internal potential.

Sales of renewable fuel briquettes to selected customers (PLN)

Coniferous timber acquisition $\left(\mathrm{m}^{3}\right)$

Number of regular customers in the enterprises surveyed

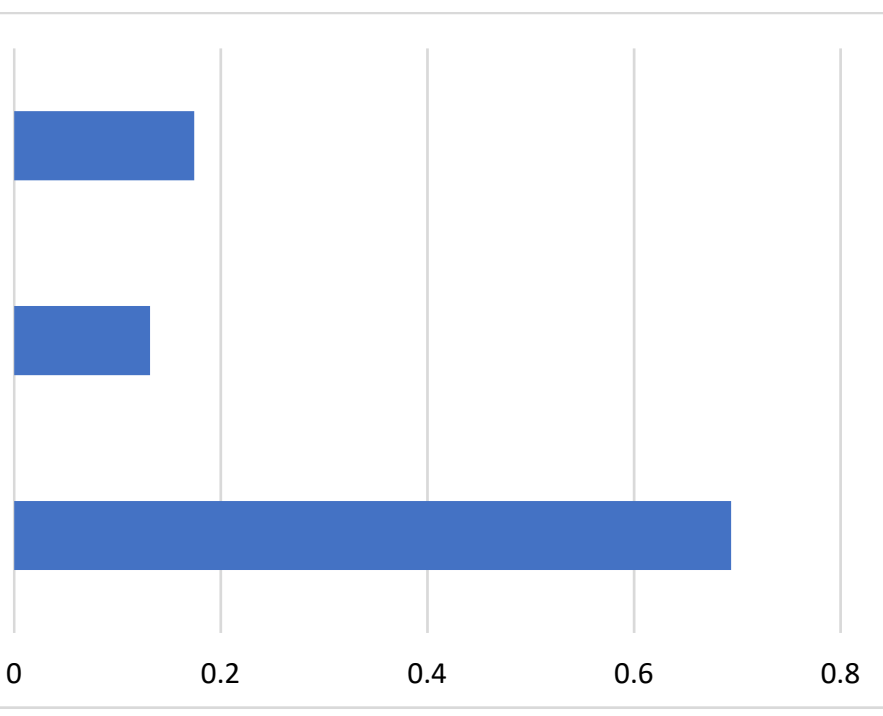

Figure 7. Weight values.

\section{Conclusions and Discussion}

Plant materials for energy purposes have recently become very popular-particularly forest biomass, which also belongs to this group. Forest biomass in the form of logging residues is now used for energy purposes as well [76,77]. It must be emphasized that wood by-products are both a valuable alternative raw material for the wood processing sector 
(alternative to harvesting trees specifically for this purpose), as well as an energy source that is an alternative to fossil fuels in the energy sector [76-79].

The analyses conducted show that there are a group of factors that influence the development of enterprises operating in the field of logging residue management. The following factors were selected for the analysis: conifer timber harvesting, sales of renewable fuel in the form of briquettes to selected customers, and the number of the given company's regular customers. Based on the analyses conducted using ANOVA, it was determined that the number of enterprises in the voivodeship was only significantly affected by the number of renewable fuel briquettes sold to selected customers. Therefore, due to the sales of renewable fuel in the form of briquettes to selected customers, the greatest development prospects for wood industry companies existed in the Małopolskie, Mazowieckie, Ślaskie and Wielkopolskie Voivodeships. The AHP method also showed that the sales of renewable fuel briquettes to selected customers are the biggest influencing factor.

On the other hand, the analysis did not show that coniferous timber harvested in the given voivodeship and the number of regular customers affected the business prospects in the voivodeships analyzed. However, it is worth noting that the number of renewable fuel briquettes sold was significantly positively correlated with the number of customers. In turn, the lack of impact of coniferous timber harvesting in the given voivodeship on the number of enterprises in it may be due to such things as the ease of transporting timber to other locations, as well as logging residues. As emphasized in the study by Schnorf et al. [80], transporting wood is more efficient than transporting manure, for example, which is also used for energy purposes. Moreover, they also report in their study that wood chip transportation distances may be as large as $477 \mathrm{~km}$. In the case of Poland, this would mean transporting them across nearly the entire country.

The issue described in the article is in line with research concerning business development in rural areas. Further analysis using different methods is also required. An interesting research direction could be to analyze the wood biomass spatial diversity potential with the cluster analysis method. Conducting detailed analyses of selected companies, including spatial analyses concerning suppliers and customers alike, could be an interesting second direction for future research. For this purpose, gravity models in the determination and analysis of locations should be used. This would make it possible to determine the optimal locations for establishing wood processing enterprises supplying wood for energy purposes.

Author Contributions: Conceptualization, K.R., M.R. (Michał Roman), M.W.-Z. and M.R. (Monika Roman); Data curation, K.R., M.R. (Michał Roman) and M.R. (Monika Roman); Formal analysis, K.R., M.R. (Michał Roman), M.W.-Z. and M.R. (Monika Roman); Funding acquisition, K.R., M.R. (Michał Roman), M.W.-Z. and M.R. (Monika Roman); Investigation, K.R., M.R. (Michał Roman), M.W.-Z. and M.R. (Monika Roman); Methodology, K.R., M.R. (Michał Roman) and M.R. (Monika Roman); Project administration, K.R., M.R. (Michał Roman), M.W.-Z. and M.R. (Monika Roman); Resources, K.R., M.R. (Michał Roman) and M.R. (Monika Roman); Software, K.R., M.R. (Michał Roman), M.W.-Z. and M.R. (Monika Roman); Supervision, K.R., M.R. (Michał Roman), M.W.-Z. and M.R. (Monika Roman); Validation, K.R., M.R. (Michał Roman), M.W.-Z. and M.R. (Monika Roman); Visualization, K.R., M.R. (Michał Roman), M.W.-Z. and M.R. (Monika Roman); Writing-Original draft preparation, K.R., M.R. (Michał Roman), M.W.-Z. and M.R. (Monika Roman); Writing-Review and editing, K.R., M.R. (Michał Roman), M.W.-Z. and M.R. (Monika Roman). All authors have read and agreed to the published version of the manuscript.

Funding: This research received no external funding.

Institutional Review Board Statement: Not applicable.

Informed Consent Statement: Not applicable.

Data Availability Statement: Not applicable.

Conflicts of Interest: The authors declare no conflict of interest. 


\section{References}

1. Lin, B.; Lin, J. Evaluating energy conservation in China's heating industry. J. Clean. Prod. 2017, 142, 501-512. [CrossRef]

2. Dyrektywa 2003/87/WE Parlamentu Europejskiego i Rady z Dnia 13 Października 2003 r. Ustanawiająca System Handlu Przydziałami emisji Gazów Cieplarnianych We Wspólnocie Oraz Zmieniająca Dyrektywę Rady 96/61/WE s. 631. Available online: https:/ / eur-lex.europa.eu/legal-content/PL/TXT/PDF/?uri=CELEX:32003L0087\&from=pl (accessed on 15 June 2021).

3. Bureau, D.P.; Kaushik, S.J.; Cho, C.Y. Bioenergetics. In Fish Nutrition, 3rd ed.; Elsevier: Amsterdam, The Netherlands, 2003; pp. 1-59. [CrossRef]

4. Buttgereit, F.; Burmester, G.R.; Brand, M.D. Bioenergetics of immune functions: Fundamental and therapeutic aspects. Immunol. Today 2000, 21, 194-199. [CrossRef]

5. Dziennik Ustaw Nr 261, poz. 2187 z Dnia 19 Grudnia 2005 r. w Sprawie Szczegółowego Zakresu Obowiązków Uzyskania i Przedstawienia do Umorzenia Świadectw Pochodzenia, Uiszczenia Opłaty Zastępczej, Zakupu Energii Elektrycznej i Ciepła Wytworzonych w Odnawialnych źródłach Energii, §2 ust. 1. Available online: http://isap.sejm.gov.pl/isap.nsf/download.xsp/ WDU20052612187/O/D20052187.pdf (accessed on 15 June 2021).

6. Blicharska, M.; Angelstam, P.; Elbakidze, M.; Axelsson, R.; Skorupski, M.; Węgiel, A. The Polish Promotional Forest Complexes: Objectives, implementation and outcomes towards sustainable forest management? For. Policy Econ. 2012, 23, 28-39. [CrossRef]

7. Fang, J.; Chen, A.; Peng, C.; Zhao, S.; Ci, L. Changes in Forest Biomass Carbon Storage in China between 1949 and 1998. Science 2001, 292, 2320-2322. [CrossRef] [PubMed]

8. Kalinowski, M.; Huz, M. Rozwój Metodyki Badań i Projektowania Rozwiązań Praktycznych w Zakresie Wykorzystania Biomasy Leśnej do Celów Energetycznych; Synteza Instytut Badawczy Leśnictwa: Sękocin Stary, Poland, 2010; pp. 5-6.

9. Jensen, P.D.; Mattson, J.E.; Kofman, P.D.; Klausner, A. Tendency of wood fuels from whole trees, logging residues and roundwood to bridge over openings. Biomass Bioenergy 2004, 26, 107-113. [CrossRef]

10. Malinen, J.; Pesonen, M.; Maatta, T.; Kajanus, M. Potential harvest for wood fuels (energy wood) from logging residues and first thinnings in Southern Finland. Biomass Bioenergy 2001, 20, 189-196. [CrossRef]

11. Ollson, B.A.; Akerblom, S.; Bishop, K.; Eklof, K.; Rin, E. Does the harvest of logging residues and wood ash application affect the mobilization and bioavailability of trace metals? For. Ecol. Manag. 2017, 383, 61-72. [CrossRef]

12. Wasiak, A. Raport o Stanie Lasów w Polsce; Lasy Państwowe; Centrum Informacyjne Lasów Państwowych: Warszawa, Poland, 2013; pp. 1-103.

13. Zastocki, D.; Moskalik, T.; Sadowski, J.; Lisiecki, J. Wybrane wskaźniki techniczno-ekonomiczne pozyskania drewna na przykładzie Nadleśnictwa Radzyń Podlaski w latach 2006-2012. Stud. Mater. Cepl. Rogowie 2014, 16, $216-223$.

14. Główny Urząd Statystyczny w Warszawie, Bank Danych Lokalnych. Available online: https://bdl.stat.gov.pl/BDL/start (accessed on 12 January 2021).

15. Jarvinen, T.; Agar, D. Experimentally determined storage and handling properties of fuel pellets made from torrefied whole-tree pine chips, logging residues and beech stem wood. Fuel 2014, 129, 330-339. [CrossRef]

16. Jonsell, M.; Hansson, J.; Wedmo, L. Diversity of saproxylic beetle species in logging residues in Sweden-Comparisons between tree species and diameters. Biol. Concervation 2007, 138, 89-99. [CrossRef]

17. Iwald, J.; Lofgren, S.; Stendahl, J.; Karltun, E. Acidifying effect of removal of tree stumps and logging residues as compared to atmospheric deposition. For. Ecol. Manag. 2013, 290, 49-58. [CrossRef]

18. Dwivedi, P.; Bailis, R.; Khanna, M. Is Use of Both Pulpwood and Logging Residues Instead of Only Logging Residues for Bioenergy Development a Viable Carbon Mitigation Strategy? Bioenergy Res. 2014, 7, 217-231. [CrossRef]

19. Kubiak, M.; Różański, H. Charakterystyka techniczna rębnych drzew i drzewostanów sosnowych pod kątem mechanizacji prac pozyskaniowych. In Dokumentacja AR-IBL; Warszawa, Poland, 1985; p. 23.

20. Варес, В.; Каськ, Ю.; Муисте, П.; Пиху, Т.; Соосаар, С. Справочник потребителя биотоплива [Poradnik użytkownika biopaliwa]. Таллиннский технический университет. Таллинн 2005, 147.

21. Nurek, T.; Gendek, A.; Roman, K. Forest Residues as a Renewable Source of Energy: Elemental Composition and Physical Properties. BioResources 2018, 14, 6-20. [CrossRef]

22. Grosse, T.; Hardt, Ł. Sektorowa czy Zintegrowana, czyli o OPTYMALNEJ Strategii Rozwoju Polskiej wsi; Pro Oeconomica-Fundacja Ewaluacji i Badań Ekonomicznych: Warszawa, Poland, 2011.

23. Kłodziński, M. Dywersyfikacja gospodarki ważnym celem polityki wiejskiej. In Uwarunkowania Ekonomiczne Polityki Rozwoju Polskiej wsi i Rolnictwa; Drygas, M., Zawalińska, K., Eds.; IRWiR PAN: Warszawa, Poland, 2012.

24. Mölders, T. Multifunctional agricultural policies: Pathways towards sustainable rural development? Int. J. Soc. Agric. Food 2014, 21, 97-114.

25. Sattler, C.; Nagel, U.J. Factors affecting farmers' acceptance of conservation measures-A case study from north-eastern Germany. Land Use Policy 2010, 27, 70-77. [CrossRef]

26. Zegar, J.S. Ekonomika rolnictwa versus ekonomia agrarna. In Wieś i Rolnictwo w Procesie Zmian. Rolnictwo w Nowym Otoczeniu Rynkowym i Instytucjonalnym; Bisaga, S.A., Ed.; Wydawnictwo Uniwersytetu Opolskiego: Opole, Poland, $2010 ;$ pp. 13-24.

27. Zając, D. Znaczenie Pozarolniczej Działalności Gospodarczej Rolników w Procesie Rozwoju Wielofunkcyjności Rolnictwa i Obszarów Wiejskich; Prace Naukowe Wydziału Ekonomii Uniwersytetu Rzeszowskiego, Seria: Monografie i Opracowania 17; Wydawnictwo Uniwersytetu Rzeszowskiego: Rzeszów, Poland, 2014. 
28. Czubak, W. Rozwój Rolnictwa w Polsce z Wykorzystaniem Wybranych Mechanizmów Wspólnej Polityki Rolnej Unii Europejskiej; Wydawnictwo Uniwersytetu Przyrodniczego w Poznaniu: Poznań, Poland, 2013.

29. Tocco, B.; Bailey, A.; Davidova, S. Determinants to Leave Agriculture and Change Occupational Sector; Evidence from Enlarged EU; Univertisty of Kent, School of Economics: Seville, Spain, 2013.

30. Rosner, A. Zróżnicowanie przestrzenne obszarów wiejskich a pożądane kierunki ich rozwoju. In Obszary Wiejskie. Wielofunkcyjność. Migracje. Nowe Wizje Rozwoju; Kamińska, W., Heffner, K., Eds.; STUDIA KPZK PAN, Tom CXXXIII: Warszawa, Poland, 2011.

31. Wilkin, J. Wielofunkcyjność rolnictwa-Nowe ujęcie roli rolnictwa w gospodarce i społeczeństwie. In Wielofunkcyjność Rolnictwa. Kierunki Badań, Podstawy Metodologiczne i Implikacje Praktyczne; Wilkin, J., Ed.; IRWiR PAN: Warszawa, Poland, 2010.

32. Poulsen, M.; Spiker, M. Integrating Urban Farms into the Social Landscape of Cities. Recommendations for Strengthening the Relationship between Urban Farms and Local Communities; Johns Hopkins Bloomberg School of Public Health: Baltimore, MD, USA, 2014.

33. Stanny, M.; Rosner, A.; Komorowski, Ł. Monitoring Rozwoju Obszarów Wiejskich. Etap III. Struktury Społeczno-Gospodarcze, ich Przestrzenne Zróżnicowanie i Dynamika; EFRWP, IRWiR PAN: Warszawa, Poland, 2018.

34. Trojak, M. Regionalne Zróżnicowanie Rozwoju Ekonomicznego Polski (Differences in Economic Development between POLISH REGIONS); Publishing House of the Jagiellonian University: Krakow, Poland, 2013.

35. Roman, M.; Roman, M.; Prus, P.; Szczepanek, M. Tourism Competitiveness of Rural Areas: Evidence from a Region in Poland. Agriculture 2020, 10, 569. [CrossRef]

36. Antoneli, V.; Pulido-Fernández, M.; Bednarz, J.A.; Brandes, L.; Vrahnakis, M.; Kazoglou, Y.; Lozano-Parra, J.; García-Marín, R. Changes in Water Quality of the River das Antas as It Passes through Rural and Urban Areas. Urban. Sci. 2021, 5, 22. [CrossRef]

37. Schelisch, L.; Walter, R. Digital Networking in Home-Based Support of Older Adults in Rural Areas: Requirements for Digital Solutions. Sustainability 2021, 13, 1946. [CrossRef]

38. Schimmenti, E.; Viola, E.; Funsten, C.; Borsellino, V. The Contribution of Geographical Certification Programs to Farm Income and Rural Economies: The Case of Pecorino Siciliano PDO. Sustainability 2021, 13, 1977. [CrossRef]

39. Roman, M.; Roman, M. Milk Market Integration between Poland and the EU Countries. Agriculture 2020, 10, 561. [CrossRef]

40. Lahmar, R. Adoption of conservation agriculture in Europe: Lessons of the KASSA project. Land Use Policy 2010, 27, 4-10. [CrossRef]

41. Halamska, M.; Stanny, M.; Wilkin, J. Ciagłość i Zmiana. Sto lat Rozwoju Wsi Polskiej (Continuity and Changes. A Centenary of Rural Development in Poland); SCHOLAR Scientific Publishing House, Institute of Rural and Agricultural Development of the Polish Academy of Sciences: Warsaw, Poland, 2019.

42. Duarte, A.; Northcote, J. Investigating farmers' involvement in value-added activities: A preliminary study from Australia. Br. Food J. 2013, 115, 1407-1427. [CrossRef]

43. Wojcieszak, M. Uwarunkowania Rozwoju Turystyki Przyrodniczej na Obszarach Metropolitalnych i Jego Efekty Ekonomiczne (Conditions for, and Economic Effects of, the Development of Nature Tourism in Metropolitan Areas); Publishing House of the Poznan University of Life Sciences: Poznań, Poland, 2017.

44. Yang, Y. Understanding tourist attraction cooperation: An application of network analysis to the case of Shanghai. J. Destin. Mark. Manag. 2017, 8, 396-411. [CrossRef]

45. Kiryluk-Dryjska, E.; Beba, P.; Poczta, W. Local determinants of the Common Agricultural Policy rural development funds' distribution in Poland and their spatial implications. J. Rural Stud. 2020, 74, 201-209. [CrossRef]

46. Zając, S. Badania wpływu gospodarki leśnej na ekonomiczno-społeczny rozwój kraju—Cele, metody, wyniki. Poznańskie Towarzystwo Przyjaciół Nauk. Wydział Nauk Rolniczych i Leśnych. For. Lett. 2013, 104, 74-86.

47. Staniszewski, P. Uwarunkowania Budowy Systemu Niedrzewnego Użytkowania Lasu. Rozprawy Naukowe i Monografie, Seria 425; Wydawnictwo SGGW: Warszawa, Poland, 2013; ISBN 978-83-7583-458-1.

48. Degórski, M. Infrastrukturalna wartość lasów. Lasy w zagospodarowaniu przestrzennym i kształtowaniu krajobrazu; społecznokulturowe wartości lasu w przestrzeni (w środowisku życia człowieka). In Lasy jako Czynnik Rozwoju Cywilizacji: Współczesna i Przyszła Wartość Lasów; Panel ekspertów; Instytut Badawczy Leśnictwa: Sękocin Stary, Poland, 2013.

49. Sultana, A.I.; Saha, N.; Reza, M.T. Synopsis of Factors Affecting Hydrogen Storage in Biomass-Derived Activated Carbons. Sustainability 2021, 13, 1947. [CrossRef]

50. IIASA. Study on Impacts on Resource Efficiency of Future EU Demand for Bioenergy; International Institute for Applied Systems Analysis (IIASA): Laxenburg, Austria, 2016.

51. Lauri, P.; Havlík, P.; Kindermann, G.E.; Obersteiner, M. Woody biomass energy potential in 2050. Energy Policy 2017, 66, 19-31. [CrossRef]

52. Petersson, H.; Holm, S.; Ståhl, G.; Alger, D.; Fridman, J.; Lehtonen, A.; Lundström, A.; Mäkipää, R. Individual tree biomass equations orbiomass expansion factors for assessment of carbon stock changes in livingbiomass-A comparative study. For. Ecol. Manag. 2012, 270, 78-84. [CrossRef]

53. Kraxner, F.; Nordström, E.M.; Havlík, P.; Gusti, M.; Mosnier, A.; Frank, S.; Valin, H.; Fritz, S.; Fuss, S.; Kindermann, G.; et al. Global bioenergyscenarios-Future forest development, land-use implications, and trade-offs. Biomass Bioenergy 2013, 57, 86-96. [CrossRef]

54. Ince, P.; Kramp, A.; Skog, K. Evaluating economic impacts of expanded globalwood energy consumption with USFPM/GFPM model. Can. J. Agric. Econ. 2012, 60, 211-237. [CrossRef] 
55. Jabłoński, M.; Budniak, P. Szacowanie nadziemnej biomasy drzewnej lasów w Polsce na potrzeby sprawozdaczości EKG/FAO i UNFCCC. For. Res. Pap. 2014, 75, 277-289.

56. Ratajczak, E.; Bidzińska, G. Rynek Biomasy Drzewnej na cele Energetyczne-Aspekty Ekonomiczne i Społeczne; Biomasa leśna na cele energetyczne; Gołos, P., Kaliszewki, A., Eds.; Instytut Badawczy Leśnictwa: Sękocin Stary, Poland, 2013.

57. Bijak, S.; Zasada, M.; Bronisz, A.; Bronisz, K.; Czajkowski, M.; Ludwisiak, Ł.; Tomusiak, R.; Wojtan, R. Estimating coarse roots biomass in young silver birch stands on post-agricultural lands in central Poland. Silva. Fenn. 2013, 47, 1-14. [CrossRef]

58. Persson, T. Environmental consequences of tree stump harvesting. For. Ecol. Manag. 2013, 290, 1-4. [CrossRef]

59. Walters, J.P.; Archer, D.W.; Sassenrath, G.F.; Hendrickson, J.R.; Hanson, J.D.; Halloran, J.M.; Vadas, P.; Alarcon, V.J. Exploring agricultural production systems and their fundamental components with system dynamics modelling. Ecol. Model. 2016, 333, 51-65. [CrossRef]

60. Durlik, I. Inżynieria Zarzadzania cz.1.; Wydawnictwo Placet: Warszawa, Poland, 2007.

61. Biazzo, S.; Bernardi, G. Process management practices and quality systems standards: Risks and opportunities of the new ISO 9001 certification. Bus. Process. Manag. J. 2003, 9, 149-169. [CrossRef]

62. Zhang, Q.; Lu, X.; Peng, Z.; Ren, M. Perspective: A review of lifecycle management research on complex products in smartconnected environments. Int. J. Prod. Res. 2019, 57, 6758-6779. [CrossRef]

63. Szostak, A. Drzewne Produkty Uboczne Źródłem Biomasy Drzewnej do Celów Energetycznych; Biomasa leśna na cele energetyczne; Gołos, P., Kaliszewki, A., Eds.; Instytut Badawczy Leśnictwa: Sękocin Stary, Poland, 2013.

64. Kamimura, K.; Kuboyama, H.; Yamamoto, K. Wood biomass supply costs and potential for biomass energy plants in Japan. Biomass Bioenergy 2012, 36, 107-115. [CrossRef]

65. Walker, T.; Cardellichio, P.; Gunn, J.S.; Saah, D.S.; Hagan, J.M. Carbon Accounting for Woody Biomass from Massachusetts (USA) Managed Forests: A Framework for Determining the Temporal Impacts of Wood Biomass Energy on Atmospheric Greenhouse Gas Levels. J. Sustain. Forestry 2013, 32, 130-158. [CrossRef]

66. Field, B.C.; Campbell, J.E.; Lobell, D.B. Biomass Energy: The scale of the potential resource. Trends Ecol. Evol. 2008, 23, 65-72. [CrossRef]

67. Gust, J.; Gundolf, K.; Cesinger, B. Doing business in a green way: A systematic review of the ecological sustainability entrepreneurship literature and future research directions. J. Clean. Prod. 2017, 147, 44-56. [CrossRef]

68. Kahan, D. Entrepreneurship in Farming; Food and Agriculture Organization of the United Nations: Rome, Italy, 2012; Available online: https://www.cabdirect.org/cabdirect/abstract/20133384542 (accessed on 13 April 2021).

69. Jakubowski, J.; Sztencel, R. Wstęp do Teorii Prawdopodobieństwa; Script: Warszawa, Poland, 2004.

70. Statystyka na Piechote. Available online: http://home.agh.edu.pl $/ \sim\{\}$ bartus $/$ index.php?action=statystyka\&subaction= przedzialy_ufności (accessed on 12 January 2021).

71. Wzory na Jednoczynnikową Analizę Wariancji. Available online: http://www.naukowiec.org/wzory/statystyka/ jednoczynnikowa-analiza-wariancji_371.html (accessed on 12 January 2021).

72. Miller, G.A. The Magic Number Seven Plus or Minus Two Some Limits on our Capacity for Processing Information. Psychol. Rev. 1956, 63, 343-352. [CrossRef]

73. Saaty, R.W. The Analytic Hierarchy Process-What it is and how it is used. Math. Model. 1987, 9, 161-176. [CrossRef]

74. Rycabel, C. Metoda wyboru rodzaju piętrzenia wody dla celów energetyki rolniczej. Inżynieria Rol. 2001, 8, 349-360.

75. Pankaj, L.; Alavalapati, J.R.R.; Marinescu, M.; Rao Matta, J.; Dwivedi, P.; Susaeta, A. Developing Sustainability Indicators for Woody Biomass Harvesting in the United States. J. Sustain. For. 2011, 30, 736-755.

76. Lauri, P.; Kallio, M.; Schneider, U. Price of $\mathrm{CO}^{2}$ emissions and use of wood in Europe. Policy Econ. 2012, 15, 123-131. [CrossRef]

77. Gołos, P.; Kaliszewki, A. Biomasa Leśna na Cele Energetyczne; Instytut Badawczy Leśnictwa: Sękocin Stary, Poland, 2013.

78. Nurek, T.; Gendek, A.; Roman, K.; Dabrowska, M. The effect of temperature and moisture on the chosen parameters of briquettes made of shredded logging residues. Biomass Bioenergy 2019, 130, 105368. [CrossRef]

79. Schnorf, V.; Trutnevyte, E.; Bowman, G.; Burg, V. Biomass transport for energy: Cost, energy and $\mathrm{CO}_{2}$ performance of forest wood and manure transport chains in Switzerland. J. Clean. Prod. 2021, 293, 125971. [CrossRef]

80. Hoyne, S.; Thomas, A. Forest Residues: Harvesting, Storage and Fuelvalue, Dublin. 2015. Available online: https://www. cabdirect.org/cabdirect/abstract/20023126149 (accessed on 12 March 2021). 